\title{
Somatic cell counts, reproduction indicators, and technical efficiency in milk production: A stochastic frontier analysis for Spanish dairy farms
}

\author{
Jose A. Pérez-Méndez, ${ }^{1,2}$ (1) David Roibás, ${ }^{1,3}$ (1) and Alan Wall ${ }^{1,3 *}$ (1) \\ ${ }^{1}$ Oviedo Efficiency Group, University of Oviedo, 33006 Oviedo, Spain \\ ${ }^{2}$ Department of Accounting, University of Oviedo, 33006 Oviedo, Spain \\ ${ }^{3}$ Department of Economics, University of Oviedo, 33006 Oviedo, Spain
}

\begin{abstract}
Health and reproductive conditions affect milk yields in dairy cows and may lead to differences in technical efficiency across farms. To investigate this, we created a novel panel data set of 197 dairy farms in northern Spain observed over the period 2006-2014 by combining information from 2 different sources and including data on production variables, somatic cell count, and reproduction indicators, as well as a genetic index. We used these data to estimate a stochastic production frontier where the somatic cell count, age at first calving, and calving interval are included as determinants of technical efficiency. Higher somatic cell count, greater age at first calving, and longer calving intervals were found to decrease technical efficiency, translating into significant losses in profits which we quantify through a simulation exercise. We also quantified the effect of genetic selection on profits, taking into account not only its direct effect on productivity but also its indirect effect through reduced technical efficiency due to the effect of genetic selection on the health and reproduction variables.
\end{abstract}

Key words: animal health, somatic cell count, calving interval, genetic selection, technical efficiency

\section{INTRODUCTION}

The relationships between animal welfare indicators and productivity have been widely studied in the veterinary science and animal science literatures. One of the most accepted broad definitions of animal welfare is "the state of an animal as it attempts to cope with its environment" (Fraser and Broom, 1990), and as such, animal welfare has several facets, both physical and psychological. One of these is animal health, for which several indicators can be used depending on the health

Received June 23, 2019.

Accepted March 9, 2020.

*Corresponding author: awall@uniovi.es aspects being studied. Within the broad spectrum of animal health indicators, illnesses among dairy cows associated with high SCC and reproductive practices and disorders affect the productive performance of dairy farms. Genetic selection of high-yield cows may also lead to health and reproductive disorders. The focus of the present study is to investigate and quantify the effect of these illnesses, reproductive disorders, and genetic selection on dairy farm technical efficiency.

Whereas veterinary scientists have traditionally tended to take an animal-based approach to welfare, focusing on animal physiology, behavior, and pathologies (e.g., Hewson, 2003), economists will tend to take a human-based approach, which also takes into account education, beliefs, culture, income, and experience when attempting to determine the optimal level of animal welfare (McInerney, 2004). As an example of the economist's human-based approach, McInerney (2004) put forward a conceptual framework for analyzing the relationship between dairy cow welfare and productivity by proposing a production possibilities frontier that implied a trade-off in the sense that increases in animal welfare could only be achieved at the expense of a reduction in their productivity. However, this trade-off implies that dairy farms are producing in a technically efficient manner. If they are not, then the possibility arises of increasing both animal welfare and productivity through increases in technical efficiency. Harvey and Hubbard (2013) reflect on the political economy of farm animal welfare, which draws on McInerney (2004) for the discussion of the supply of farm animal welfare. These authors contend that consumption externalities are the major cause of market failure in the case of farm animal welfare and argue strongly in favor of policies to subsidize the consumption of animal welfare-friendly products. A theoretical framework for the relationship between animal welfare and the economic performance of livestock farms that gives rise to similar conclusions was provided by Henningsen et al. (2018).

To contribute to the literature on animal welfare and productivity, we analyzed the relationship between 
productive performance, measured with estimates of technical efficiency, and indicators of health and reproductive practices for a sample of Spanish dairy farms. We used panel data on dairy farms in the northern Spanish region of Asturias, which combines production variables (inputs and outputs) with the health and reproductive practice indicators. The health indicator we used is the SCC in milk, which is an indicator of the general state of health of the mammary glands of milking cows. High levels of SCC are associated with mastitis, a common illness among dairy cows, and lower quality of milk or even rejection of the milk by distributors (Huijps et al., 2008; Pritchard et al., 2013). As an indicator of the health of the herd, the SCC may reflect sub-optimal management on the part of the farmer and we would expect a negative relation between SCC and technical efficiency. On the other hand, poor reproductive performance has been found to lower the quantity of milk produced per cow (Lawson et al., 2004b). As indicators of the reproductive practices of the herd, we used calving interval (CIN) and age at first calving (AFC). We used these data to estimate a stochastic production frontier where the SCC and reproductive practice indicators are included as determinants of technical inefficiency. Our objective was to assess how these indicators affect technical inefficiency and to quantify these effects with a simple simulation analysis.

Our work makes various contributions to the literature. First, we add to what is still a relatively small literature on the relationship between animal health indicators and technical efficiency. Second, we have been able to obtain a novel, high-quality data set that we constructed by bringing together data from 2 sources, allowing us to combine production data with SCC and reproduction variables. Third, we not only estimate the effect of the SCC and reproduction variables on technical efficiency but also simulate their effects on farm profits. Finally, we bring genetic selection, which is another component of animal health, into the analysis and estimate its effect on profits. We use simulation analysis to calculate both the direct effect of genetic selection on profits, due to increases in productivity, as well as its indirect effect, which is due to the influence of genetic selection on technical inefficiency via the changes it produces in animal health and reproduction indicators. As far as we are aware, ours is the first paper to analyze these effects in a production frontier framework.

\section{MATERIALS AND METHODS}

As far as the related literature on dairy cow welfare and productive performance is concerned, at a general level Lusk and Norwood (2011) discussed how production economics, welfare economics, and consumer theory can contribute to the debate about animal welfare. On a more specific level, several studies have addressed the relationships between the welfare of dairy cattle and productivity. von Keyserlingk et al. (2009) argued that a low level of animal welfare can lead to low productivity, citing a series of studies that show how different types of illnesses and stress can lead to low milk yields. In accordance with the conceptual framework provided by McInerney (2004), on the other hand, high cow productivity may be associated with low levels of animal welfare if farmers are producing efficiently. One of the reasons for this inverse relationship is the genetic selection of cows with the aim of achieving higher yields, which has been found to be correlated with health problems such as lameness, mastitis, fertility problems, and lower longevity (Oltenacu and Algers, 2005). A good overview of the relationship between genetic selection criteria and health and reproductive problems among dairy cattle can be found in Pritchard et al. (2013).

Regarding the relationship between animal health indicators and productivity, Halasa et al. (2007) carried out a review of studies that attempt to quantify the economic effects of mastitis and concluded that milk production losses due to mastitis are directly related to SCC. Huijps et al. (2008) quantified economic losses due to mastitis for a sample of Dutch dairy farms and found that the majority of farmers underestimate these economic losses. With regard to CIN, Dono et al. (2013) analyzed a sample of 50 Italian dairy farms, which they divided into 2 production systems based on a clustering. They found that the most productive system was characterized by shorter CIN and a more efficient use of feed.

Although abundant literature is available in the veterinary and animal sciences on the relation between the management of animal health and reproduction and milk production, the economic literature is much smaller and few studies have used frontier techniques. Lawson et al. (2004a,b) used stochastic frontier analysis to study the effects of a series of illnesses and reproductive disorders on the technical efficiency of Danish dairy farms. The adverse effects of reproductive disorders on milk production were found to be compensated by good managerial decisions in efficient farms. Calving intervals were one of the reproductive indicators used, but it was not found to have an effect on efficiency. Hansson and Öhlmér (2008) used data envelopment analysis (DEA) to analyze the effects of animal breeding, health, and feeding practices for Swedish dairy farms, finding that breeding practices influenced efficiency but that the sample was already quite homogeneous in terms of 
health practices so these did not have scope to provide further efficiency gains. Also using DEA, Hansson et al. (2011) analyzed the effects of preventative measures against mastitis on dairy farm efficiency, identifying measures that increased efficiency when SCC scores were found to be too high. The relation between lameness and technical efficiency was analyzed by Barnes et al. (2011) for a sample of British dairy farms using DEA, who found that lower frequency of lameness was associated with higher technical efficiency. Allendorf and Wettemann (2015) investigated how a series of animal welfare indicators affected the technical efficiency of German dairy farms using DEA and a censored regression model. They found, among other results, that a longer CIN had a negative effect on technical efficiency, whereas a higher SCC had a positive effect on technical efficiency. Allendorf and Wettemann (2015) explained the counterintuitive latter result as probably being due to the fact that their sample had only 2 observations out of 575 with an SCC above the level at which milk would be classified as lower quality and price penalties imposed. Finally, Schulte et al. (2018) examined the relationship between dairy cow welfare and technical efficiency for a sample of German dairy farms using both standard DEA and a stochastic directional distance function approach. The authors found evidence of a positive correlation between technical efficiency and dairy cow welfare, such that no trade-off between the 2 exists. Schulte et al. (2018) also investigated the role of pasture access in animal welfare and technical efficiency. These authors concluded that pasture access does not guarantee higher levels of animal welfare, bringing into question government policies supporting pasture access as a means of increasing animal welfare.

Whereas the studies referred to above have generally explored the possibility of increasing both animal welfare and technical efficiency, recent literature on rational inefficiency explored the possibility that some farmers may deliberately trade off increased animal welfare against technical efficiency (Hansson et al., 2018). The justification for this is that such farmers are assumed to perceive non-use values from this trade-off. This possibility was put forward by McInerney (2004), who argued that farmers may supply levels of animal welfare beyond what would be economically optimal due to the existence of these non-use values.

Our review of the literature on the relationship between dairy cow welfare and farm productivity points to the possibility that both welfare and productivity may be increased if farms are not producing efficiently. The studies cited above that have used production frontier techniques show that SCC and reproductive practices and disorders influence efficiency. Moreover, the literature suggests that genetic selection, used to generate higher milk yields, may lead to health disorders, which implies that the selection decision implies a trade-off between animal health and productivity. In our empirical work, to which we now turn, we draw on these insights from the literature to investigate the relationship between SCC, reproduction indicators, genetic selection, and farm technical efficiency using a production frontier model.

To carry out our empirical application we used a novel data set of dairy farms located in the region of Asturias in northwest Spain, one of main milk-producing regions in that country. The data used in the empirical analysis comprise an unbalanced panel of 1,160 observations corresponding to 197 dairy farms observed during the 9-yr period from 2006 to 2014. These are specialized dairy farms, with milk accounting for over $90 \%$ of sales revenues. Two data sets were combined to form this panel, which includes production data (inputs and output) and possible determinants of inefficiency. First, production data (inputs and outputs), as well as some determinants of inefficiency involving farm characteristics, came from a voluntary record-keeping program in which these farms were enrolled. This record-keeping program is run by the regional government and gathers information on 9 Dairy Farmer Management Associations located in the region. The main objective of these associations, which are funded by the regional government, is to provide managerial and technical advice to their affiliates. A technical expert visits each farm on a monthly basis to collect the data necessary for the managerial advisory service, and this monthly information is then combined with annual inventories to prepare an annual report on each farm. Second, the data for the animal health and reproduction indicators that we used as determinants of inefficiency were provided by a breeder's cooperative, the Asturian Milk Control Cooperative (ASCOL). The ASCOL, founded in 1986, is a cooperative with more than 1,000 milk producers affiliated that specializes in genetic selection services for its members. The cooperative provides high-quality data on, among other variables, SCC, AFC, CIN, and a genetic index (GI) for milk yield, and we have been able to cross this information with the production data.

In our empirical model we used 1 output, 6 production inputs, a control variable (GI), and 7 determinants of inefficiency. The dependent variable in the stochastic frontier model is milk, which represents milk production and is measured in liters. The 6 inputs are as follows. Labor includes family labor and hired labor and is measured using Social Security expenses; these are mandatory payments that must be made by the farm for each worker, including part-time workers. Cows is defined 
as the number of adult cows in the herd, where all the farms in the sample use Holstein-Friesian cows. The next input, abbreviated as Conc, is the amount of concentrate feed used by the farm, measured in kilograms. This is concentrate feed used by productive cows only and does not include feed used to raise heifers to lactation. Expenditure on forage production is defined as the costs of seeds, fertilizer, fuel, land, other raw materials, and machinery hire and amortization. The next input is expenditure on the acquisition of forage. The last production input is animal expenditure, which includes expenditure on veterinary services, milking, electricity, water, and the amortization of buildings and technical installations. The use of the categories "forage production expenses" and "animal expenses" as inputs can also be found in Orea et al. (2015) and Pérez-Méndez et al. (2019), among others. We highlight that our inputs were chosen in an attempt to measure the physical quantity of inputs used to produce milk. This basically includes cows, concentrate feed, purchases of forage, and forage produced by the farmer (which is proxied by the expenditure involved in producing it). For this reason, the input Conc refers to concentrate feed that is consumed by productive cows only. All the monetary variables are expressed in 2014 euro $(€)$, where $€ 1=$ US $\$ 1.214$ on December 31, 2014, and the Consumer Price Index has been used as a deflator. Finally, we included a GI of the herd, which can be considered as the outcome of a genetic selection process, to control for endogeneity between the inputs and the error term. The GI for milk yield in our database is calculated using the animal model and is reported in kilograms of milk per lactation. The GI of each herd is calculated as the arithmetic mean of the individual GI for each cow in the herd. More details can be found in Roibas and Alvarez (2010).

The determinants of inefficiency are divided between farm characteristics and animal health and reproduction indicators. The farm characteristics were drawn from determinants used in the existing literature, in particular Cabrera et al. (2010) and del Corral et al. (2011). The first is CPC, which is concentrate feed per cow and controls for the level of intensification of the farm. We would expect this variable to be positively associated with technical efficiency, as previous studies (e.g., del Corral et al., 2011) have found that more intensive production systems are more efficient. Second, POL is the proportion of own land, defined as the ratio of owned land to total land. The effect of this on efficiency is unclear a priori. On one hand, a higher proportion of own land could reflect greater accumulation of land due to efficient behavior in the past by the farmer, in which case POL might be expected to be associated with higher efficiency. On the other hand, investment in land is not usual in the case of Asturian dairy farmers. Land is commonly increased by renting it from farmers who have retired and abandoned productive activity, which implies that more expansion-oriented farmers may have a greater proportion of rented land. In this case, more own land (and hence less rented land) would be associated with higher inefficiency. Either hypothesis is plausible. The final farm characteristic is the proportion of family labor (PFL), defined as the ratio of family labor to total labor. Again, the effect on efficiency here is unclear a priori. On one hand, family members may be more motivated than externally hired workers. On the other, the hiring of external workers may point to a dynamic, expanding successful operation, so that external workers may be a sign of greater efficiency.

The health and reproduction indicators, from AS$\mathrm{COL}$, are $\mathrm{SCC}, \mathrm{AFC}$, and CIN. The AFC is measured in days. The CIN measures the average number of days between 2 consecutive births. To calculate the SCC, monthly reports are analyzed for each farm that contain SCC for all milking cows. The cell count in these reports is a weighted average by liters of milk per cow, and the annual figure for each farm is calculated as the geometric mean of the individual values of each control. We note here that data on the SCC are also available from the regional government's record-keeping program database. However, these data have the drawback that they are calculated from the somatic cells contained in the milk that is supplied to the distributors and therefore do not take into account the milk that has been discarded due to excessively high SCC in certain cows at given points in time. The data provided by ASCOL, on the other hand, are based on analyses carried out on each individual cow in the herd, and therefore represent a much more reliable indicator of the state of health of the herd than the cell count calculated based on the milk supplied to the distributors. As previous studies (Wilmink, 1987; Mostert et al., 2001) have established relationships between age and productivity, we also included the age of the herd (HA), defined as the average age of the herd expressed in years, as a determinant of inefficiency. The square of this variable was also included to pick up any potential nonlinear effects of herd age.

Before presenting the descriptive statistics of the data and the model to be estimated, some words are in order about the health and reproduction variables we used as determinants of inefficiency. We consider that these variables capture different facets of animal welfare. The SCC is an indicator of animal health as higher values are associated with a greater incidence of 
mastitis, and as such SCC is an obvious component of animal welfare. Our expectation is that this variable should be negatively related to technical efficiency.

The AFC and CIN reflect the reproduction status of the animals, which also affects animal welfare. According to McConnel et al. (2008), the CIN represents several facets of a reproductive health and management. The AFC is also related to production and health indicators. Sherwin et al. (2016) referred to several studies that have highlighted the effect of AFC on production and health indices, citing studies that show that a lower age was associated with increased survival. Sherwin et al. (2016) found that increasing the AFC over 24 mo of age was found to be significantly associated with an increased risk of being culled during the first lactation. Eastham et al. (2018) highlighted, in the case of United Kingdom, the importance of achieving a lower AFC, which they found was associated with improved udder health, increased lifetime daily milk yield, improved reproductive performance, and increased likelihood of calving for a second time. Finally, Vacek et al. (2008) found that cows with health disorders take longer to inseminate for the first time and need more inseminations later to conceive.

As affiliates of ASCOL, the farms in our sample take part in reproductive management programs in which different goals are set, including target values of CIN and AFC. The achievement of these objectives depends on the training and management ability of farmers, and later AFC and greater CIN will be reflected in lower production due to inefficient management. As such, we expect both variables to be negatively related to technical efficiency. However, although we expect that higher values of these reproductive variables would be associated with lower technical efficiency, is not obvious that higher values of these variables reflect lower animal welfare. It may be the case that farmers, in line with rational inefficiency literature referred to earlier, choose to delay the first calving and lengthen the intervals between calving and therefore accept lower production if they consider that this increases animal welfare. That is, higher values of the reproductive variables may reflect a trade-off between technical efficiency and animal welfare.

In light of the previous literature, and given that the farmers are provided technical support to keep the AFC and the intervals between calving within tight ranges, we consider that greater values of AFC and CIN may be associated with reproduction or health disorders as well as inefficient management. To support this, we investigated the relationship between AFC, CIN, and the average number of inseminations per calving for our sample by running a panel data (fixed effects) regression of the number of inseminations on AFC and CIN. We found that both coefficients were positive. Denoting the individual effects by $\alpha_{i}$, the estimated loglinear relationship was $\ln$ (inseminations) $=\alpha_{i}+1.571$ $\times \ln (\mathrm{CIN})+0.203 \times \ln (\mathrm{AFC})$, where the coefficients were statistically significant at the $1 \%$ level with standard errors of 0.080 and 0.070 , respectively.

Descriptive statistics of the production variables and inefficiency determinants are provided in Table 1. Differences among farms are quite large as the standard deviation of milk production is $75 \%$ of the mean production. The average farm size in the sample of 56 cows is substantially larger than the average Spanish farm

Table 1. Descriptive statistics of variables used in estimating stochastic production frontier

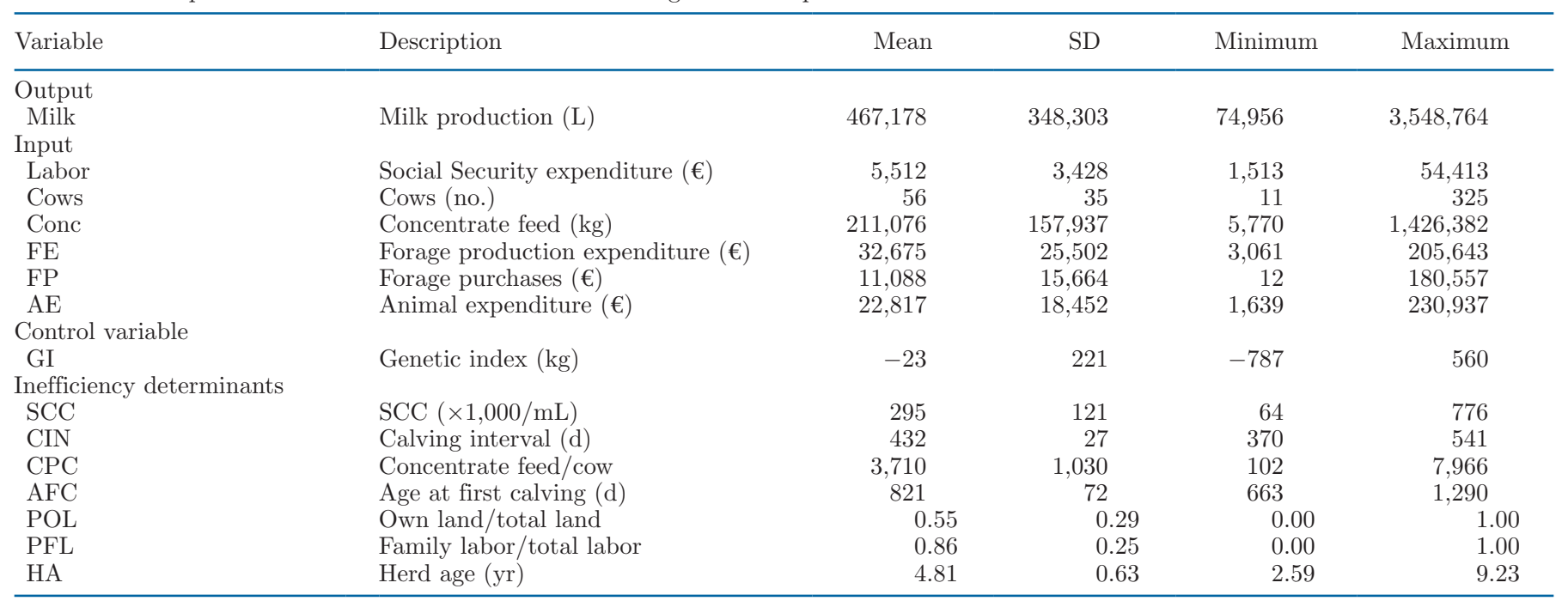


(31 cows in 2010; Eurostat, 2015) and also larger than the average farm size in some of the main milk-producing countries in Europe such as France or Germany (46 cows; Eurostat, 2015). Moreover, restructuring in recent years has led to a continual increase in farm sizes in the region.

To estimate technical efficiency and its determinants, we specify a translog functional form for the stochastic production frontier and follow Caudill et al. (1995) by allowing the determinants of inefficiency to affect the variance of the inefficiency term. The empirical model to be estimated is

$$
\begin{aligned}
& \ln y_{i t}=\sum_{i=1}^{197} \alpha_{i} D_{i}+\sum_{j=1}^{6} \beta_{j} \ln x_{j i t}+\frac{1}{2} \sum_{j=1}^{6} \sum_{k=1}^{6} \beta_{j k} \ln x_{j i t} \ln x_{k i t} \\
& +\beta_{\mathrm{GI}} \ln _{\mathrm{GI}}+\sum_{t=2007}^{2014} \alpha_{t} \mathrm{Year}_{t}+v_{i t}-u_{i t},
\end{aligned}
$$

where subscript $i$ stands for farm and $t$ for year. Subscripts $j$ and $k$ are used to index the 6 different production inputs. $y_{i t}$ is therefore the output produced by farm $i$ in year $t, x_{j i t}$ is the $j$ th input of farm $i$ in year $t$ and $\mathrm{GI}_{i t}$ is the genetic index. $v_{i t}$ is the symmetric random error term, which we assume to be normally distributed with mean zero, and $u_{i t} \geq 0$ is a one-sided error term capturing technical inefficiency. Finally, $\alpha$ and $\beta$ are the parameters to be estimated. The farm fixed effects are $D_{i}$, and Year $_{t}$ are time dummies. As the logarithm of GI enters [1], and GI has both negative and positive values, we transformed the original GI values following the procedure of Roibas and Alvarez (2010), which consists of adding a constant equal to the average production per cow minus the average GI. This value was $8,100 \mathrm{~kg}$ of milk, and adding this ensured that all transformed GI were positive. Finally, when estimating [1], the logarithms of the inputs and control variables were transformed by subtracting their sample mean. By doing so, the first-order coefficients of the inputs can be interpreted as the output elasticities for a representative farm characterized by an input endowment equal to the sample geometric mean.

Technical inefficiency is assumed to follow a halfnormal distribution, that is, $u_{i t} \sim N^{+}\left(\mathbf{0}, \sigma_{\text {uit }}^{2}\right)$, and where $\sigma_{u i t}^{2}$ is the variance of $u_{i t}$. The variance of $u_{i t}$ is specified as $\sigma_{\text {uit }}^{2}=g\left(z_{i t} ; \delta\right)$, where $z$ represents the explanatory variables and $\delta$ is a set of parameters to be estimated (Caudill et al., 1995).

$$
\begin{aligned}
& \ln \sigma_{u i t}^{2}=\delta_{0}+\delta_{\mathrm{SCC}} \ln \mathrm{SCC}_{i t}+\delta_{I} \ln \mathrm{CIN}_{i t}+\delta_{\mathrm{DFB}} \ln \mathrm{AFC}_{i t} \\
& +\delta_{C P C} \ln \mathrm{CPC}_{i t}+\delta_{\mathrm{POL}} \mathrm{POL}_{i t}+\delta_{\mathrm{PFL} \mathrm{PFL}_{i t}} \\
& +\delta_{\mathrm{HA}} \mathrm{HA}_{i t}+\delta_{\mathrm{HA}^{2}} \mathrm{HA}_{i t}^{2}
\end{aligned}
$$

where the $\delta$ are the parameters to be estimated. The conditional expectation of the technical efficiency scores can then be calculated using the following formula (Lee and Tyler, 1978; Kumbhakar and Lovell, 2000):

$$
E\left[\exp \left(-u_{i t}\right)\right]=2\left[1-\Phi\left(\sigma_{u i t}\right)\right] \exp \left(\frac{\sigma_{u i t}^{2}}{2}\right)
$$

where $\sigma_{\text {uit }}$ is the standard deviation of uit and $\Phi$ is the standard normal cumulative distribution function. We used the estimated parameter values from the estimations of the empirical model to calculate the expected technical efficiencies to carry out some simulation analyses to measure the effect on profits of changes in the values of the health and reproductive variables.

We also investigated the influence of genetics on profits. Aside from the direct effect of genetics on productive performance through the production frontier, we recognize that genetics influences the health and reproductive indicators, which will in turn give rise to indirect effects on profits thorough changes in technical efficiency. To estimate the predicted effects of changes in the GI on the health and reproductive variables (SCC, CIN, and AFC), we carried out the following 3 auxiliary regressions:

$$
\begin{gathered}
\mathrm{SCC}_{i t}=\sum_{i=1}^{197} \gamma_{i} D_{i}+\gamma_{\mathrm{GI}} \mathrm{GI}_{i t}+\gamma_{\mathrm{HA}} \mathrm{HA}_{i t}+e_{4 i t}, \\
\mathrm{CIN}_{i t}=\sum_{i=1}^{197} \mu_{i} D_{i}+\mu_{\mathrm{GI}} \mathrm{GI}_{i t}+\mu_{\mathrm{HA}} \mathrm{HA}_{i t}+e_{5 i t}, \\
\mathrm{FC}_{i t}=\sum_{i=1}^{197} \omega_{i} D_{i}+\omega_{\mathrm{GI}} \mathrm{GI}_{i t}+e_{6 i t},
\end{gathered}
$$

where $e_{4 i t}, e_{5 i t}$, and $e_{6 i t}$ are symmetric error terms. In these regressions, the SCC and CIN are modeled as functions of not only the GI but also the HA. Each regression equation includes fixed effects $\left(D_{i}\right)$, and the $\gamma, \mu$, and $\omega$ are the parameters to be estimated. 
Table 2. Estimated parameters of stochastic production frontier ${ }^{1,2}$

\begin{tabular}{|c|c|c|c|c|c|c|c|}
\hline Variable & Coefficient & SE & $P$-value & Variable & Coefficient & SE & $P$-value \\
\hline Labor & 0.010 & 0.009 & 0.295 & Conc $\times \mathrm{FE}$ & -0.022 & 0.025 & 0.375 \\
\hline Cows & 0.653 & 0.027 & 0.000 & Conc $\times$ FP & -0.025 & 0.009 & 0.005 \\
\hline Conc & 0.160 & 0.017 & 0.000 & Conc $\times \mathrm{AE}$ & -0.020 & 0.035 & 0.572 \\
\hline $\mathrm{FE}$ & 0.062 & 0.013 & 0.000 & $\mathrm{FE}$ & 0.075 & 0.027 & 0.006 \\
\hline $\mathrm{FP}$ & 0.011 & 0.005 & 0.024 & $\mathrm{FE} \times \mathrm{FP}$ & 0.003 & 0.006 & 0.611 \\
\hline $\mathrm{AE}$ & 0.087 & 0.015 & 0.000 & $\mathrm{FE} \times \mathrm{AE}$ & -0.056 & 0.025 & 0.027 \\
\hline Labor & 0.047 & 0.020 & 0.022 & $\mathrm{FP}$ & 0.002 & 0.003 & 0.468 \\
\hline Labor $\times$ cows & 0.004 & 0.038 & 0.920 & $\mathrm{FP} \times \mathrm{AE}$ & -0.001 & 0.007 & 0.838 \\
\hline Labor $\times$ Conc & -0.024 & 0.023 & 0.302 & $\mathrm{AE}$ & 0.071 & 0.038 & 0.064 \\
\hline Labor × FE & 0.009 & 0.014 & 0.511 & GI & 0.802 & 0.301 & 0.008 \\
\hline Labor $\times \mathrm{FP}$ & 0.012 & 0.006 & 0.038 & Year $_{2007}$ & -0.041 & 0.009 & 0.000 \\
\hline Labor $\times \mathrm{AE}$ & 0.001 & 0.020 & 0.961 & Year $_{2008}$ & -0.055 & 0.011 & 0.000 \\
\hline Cows & -0.064 & 0.135 & 0.635 & Year $_{2009}$ & -0.071 & 0.013 & 0.000 \\
\hline Cows $\times$ Conc & -0.049 & 0.068 & 0.477 & Year $_{2010}$ & -0.059 & 0.015 & 0.000 \\
\hline Cows $\times \mathrm{FE}$ & 0.045 & 0.043 & 0.294 & Year $_{2011}$ & -0.059 & 0.017 & 0.000 \\
\hline Cows $\times$ FP & 0.028 & 0.013 & 0.035 & Year $_{2012}$ & -0.064 & 0.019 & 0.001 \\
\hline Cows $\times \mathrm{AE}$ & -0.010 & 0.054 & 0.854 & Year $_{2013}$ & -0.064 & 0.021 & 0.002 \\
\hline Conc & 0.105 & 0.043 & 0.016 & Year $_{2014}$ & -0.034 & 0.024 & 0.145 \\
\hline
\end{tabular}

${ }^{1}$ Dependent variable: milk production (L). Number of observations $=1,160$.

${ }^{2}$ Labor $=$ Social Security expenditure; cows $=$ number of cows; Conc $=$ concentrate feed $(\mathrm{kg}) ; \mathrm{FE}=$ forage production expenditure $(€) ; \mathrm{FP}=$ purchases of forage $(€) ; \mathrm{AE}=$ expenditure on veterinary services, milking, electricity, water, and the amortization of buildings and technical installations; GI = genetic index; Year $20 \mathrm{xx}$ $=$ year dummy variables.

\section{RESULTS AND DISCUSSION}

The estimates for the production frontier are reported in Table 2 (values of the individual effects are not reported). All first-order input terms (which, given that inputs have been transformed by subtracting their sample mean, can be interpreted as output elasticities for a representative farm with inputs equal to the sample geometric mean) are positive and highly statistically significant with the exception of labor. This is a common result in studies of dairy farms where family labor represents a high proportion of total labor (e.g., Cuesta, 2000). Note from Table 1 that, on average, family labor accounts for $86 \%$ of total labor. Summing the first-order input coefficients, we find slightly decreasing returns to scale (scale elasticity $=0.983$ ). However, a Wald test of the hypothesis of constant returns to scale yielded a $P$-value of 0.39 , so that constant returns to scale cannot be rejected. Finally, the yearly dummy variables were all negative and highly significant except for the year 2014. However, this is not an unusual result given the dependence of dairy production on weather conditions (Mukherjee et al., 2013; Key and Sneeringer, 2014; Qi et al., 2015).

The estimates of the determinants of technical efficiency are reported in Table 3. All explanatory variables were found to be significant except for the ratio of family labor to total labor (PFL). The estimates for HA show that productivity is maximized in herds whose average age is $7.1 \mathrm{yr}$ old. This is consistent with other studies (Wilmink, 1987; Mostert et al., 2001) that have found production is maximized for 6- to 8-yr-old cows, although it should be noted that these studies centered on the age of the individual cows and not on the age of the herd as a whole. Of most relevance to the objectives of this study, the coefficients on SCC, CIN, and AFC were all found to be positive and highly significant, implying that increases in the values of these variables lead to increases in technical inefficiency. These results are in line with Pryce et al. (2004) who found a negative relationship between milk production and CIN. On the other hand, as the average AFC in the sample is larger than $27 \mathrm{mo}$ and the optimal AFC is between 22 and 24 mo (Ruiz-Sánchez et al., 2007), it is perhaps to be expected that technical efficiency decreases when the AFC increases.

Table 3. Estimates of technical efficiency determinants ${ }^{1,2}$

\begin{tabular}{lrrr}
\hline Variable & Coefficient & \multicolumn{1}{c}{$\mathrm{SE}$} & $P$-value \\
\hline Constant & -51.816 & 15.170 & 0.001 \\
ln SCC & 1.190 & 0.316 & 0.000 \\
ln CIN & 5.539 & 1.838 & 0.003 \\
ln AFC & 4.452 & 1.654 & 0.007 \\
ln CPC & -2.222 & 0.599 & 0.000 \\
POL & 2.161 & 0.693 & 0.002 \\
PFL & 1.737 & 1.738 & 0.318 \\
HA & -2.829 & 1.048 & 0.007 \\
HA $^{2}$ & 0.199 & 0.099 & 0.045 \\
\hline
\end{tabular}

${ }^{1}$ Dependent variable: $\log$ of technical inefficiency $\left(\ln \sigma_{u}^{2}\right)$.

${ }^{2} \mathrm{CIN}=$ calving interval; $\mathrm{AFC}=$ age at first calving; $\mathrm{CPC}=$ concentrate feed per cow; POL $=$ proportion of own land; PFL $=$ proportion of family labor; $\mathrm{HA}=$ herd age. 
Table 4. Effect of genetic index (GI) on health and reproduction variables [SCC, calving interval (CIN), age at first calving $(\mathrm{AFC})]^{1,2}$

\begin{tabular}{|c|c|c|c|c|c|}
\hline \multirow[b]{3}{*}{ Dependent variable } & \multicolumn{4}{|c|}{ Independent variable } & \multirow[b]{3}{*}{$\mathrm{R}^{2}$} \\
\hline & \multicolumn{2}{|c|}{ GI } & \multicolumn{2}{|c|}{ HA } & \\
\hline & $\begin{array}{l}\text { Coefficient } \\
\text { (SE) }\end{array}$ & $P$-value & $\begin{array}{l}\text { Coefficient } \\
\text { (SE) }\end{array}$ & $P$-value & \\
\hline $\mathrm{SCC}$ & $\begin{array}{c}0.048 \\
(0.013)\end{array}$ & 0.000 & $\begin{array}{l}38.947 \\
(6.658)\end{array}$ & 0.000 & 0.69 \\
\hline CIN & $\begin{array}{c}0.014 \\
(0.003)\end{array}$ & 0.000 & $\begin{array}{l}10.446 \\
(1.864)\end{array}$ & 0.000 & 0.50 \\
\hline $\mathrm{AFC}$ & $\begin{array}{c}-0.013 \\
(0.007)\end{array}$ & 0.060 & - & - & 0.66 \\
\hline
\end{tabular}

${ }^{1}$ Number of observations $=1,160$. All estimations carried out using individual effects (farm dummy variables). ${ }^{2}$ Results of seemingly unrelated regression estimation of system of regression equations where health and reproduction variables are expressed as functions of the GI and herd age (HA).

The average technical efficiency scores were calculated using Formula [3]. Average technical efficiency for the whole sample was 0.947 , ranging from a low of 0.723 to a maximum of 0.994 , and a standard deviation of 0.030. A histogram of the efficiency scores is presented in Figure 1 to illustrate their distribution. As can be seen, the vast majority of scores are above 0.9. Indeed, only 71 observations had scores less than 0.9. Moreover, only 13 observations had scores lower than 0.8 , and only 6 observations had scores lower than 0.75 .

Table 4 shows the results obtained from the estimation of Equations [4], [5], and [6] capturing the influence of the GI on the health and reproductive variables (SCC, CIN, and AFC), controlling for the effect of HA in the cases of the SCC and CIN. The equations have been jointly estimated using the seemingly unrelated regression estimator (Greene, 2018).

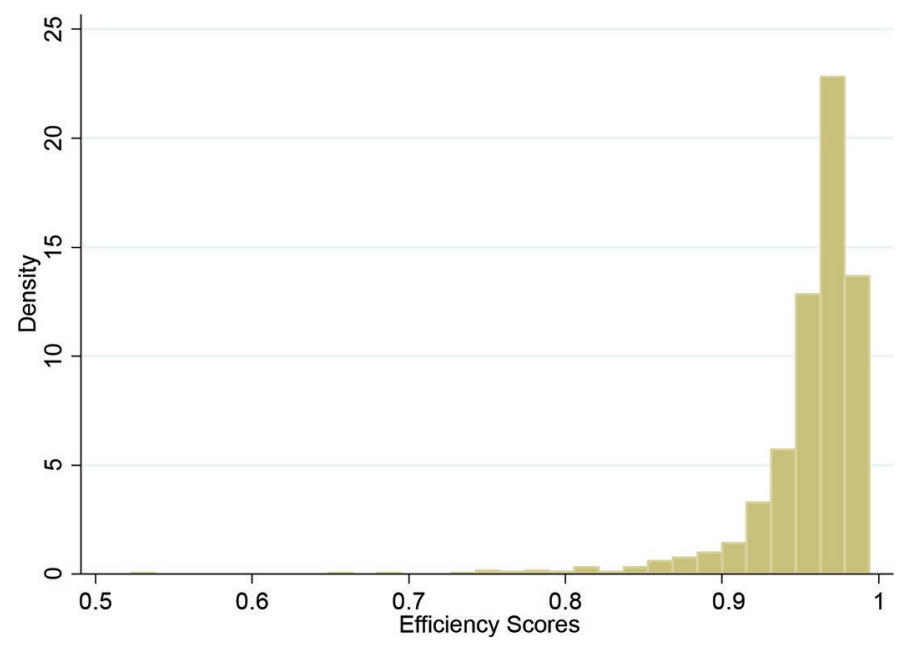

Figure 1. Histogram of estimated technical efficiency scores.
The results of the estimations are in line with the existing literature. Table 4 shows that the SCC increases with the genetic quality of the herd, in line with Castillo-Juarez et al. (2002), Carlén et al. (2004), and Zhao et al. (2015), and with the herd age (see Dohoo and Meek, 1982; Harmon, 1994; Dodenhoff et al., 1999). We see that the CIN also increases with both the GI of the herd (Campos et al., 1994; Kadarmideen et al., 2000; Pryce et al., 2000) and with the herd age, where the latter is in line with the positive relationship found by previous studies between increases in the CIN and the number of births (Nieuwhof et al., 1989). The AFC, on the other hand, is lower when the genetic quality of the herd increases (Ruiz-Sánchez et al., 2007; Ghavi Hossein-Zadeh, 2011). As pointed out by Ghavi Hossein-Zadeh (2011, p. 271), "Negative genetic correlation between AFC and yield traits in this study indicates that an increased selection based on yield traits would result in early onset of puberty."

To gain further insight into the influence of the health and reproductive indicators on productive performance, we carried out a simulation analysis using the estimated parameters from the empirical model. Focusing on the year 2014, we began by calculating the expected efficient production level $\left(y^{*}\right)$ of the representative farm, defined as the farm with inputs set equal to their sample mean values and the constant term set equal to the average of the individual effects. Thus, the $(\log )$ of the efficient production for the representative farm in 2014 can be expressed as

$$
\begin{aligned}
& \ln y_{2014}=\alpha+\sum_{j=1}^{6} \beta_{j} \ln \overline{x_{j}} \\
& +\frac{1}{2} \sum_{j=1}^{6} \sum_{k=1}^{6} \beta_{j k} \ln \overline{x_{j}} \ln \overline{x_{k}}+\beta_{\mathrm{GI}} \ln \overline{\mathrm{GI}_{i}}+\alpha_{2014},
\end{aligned}
$$




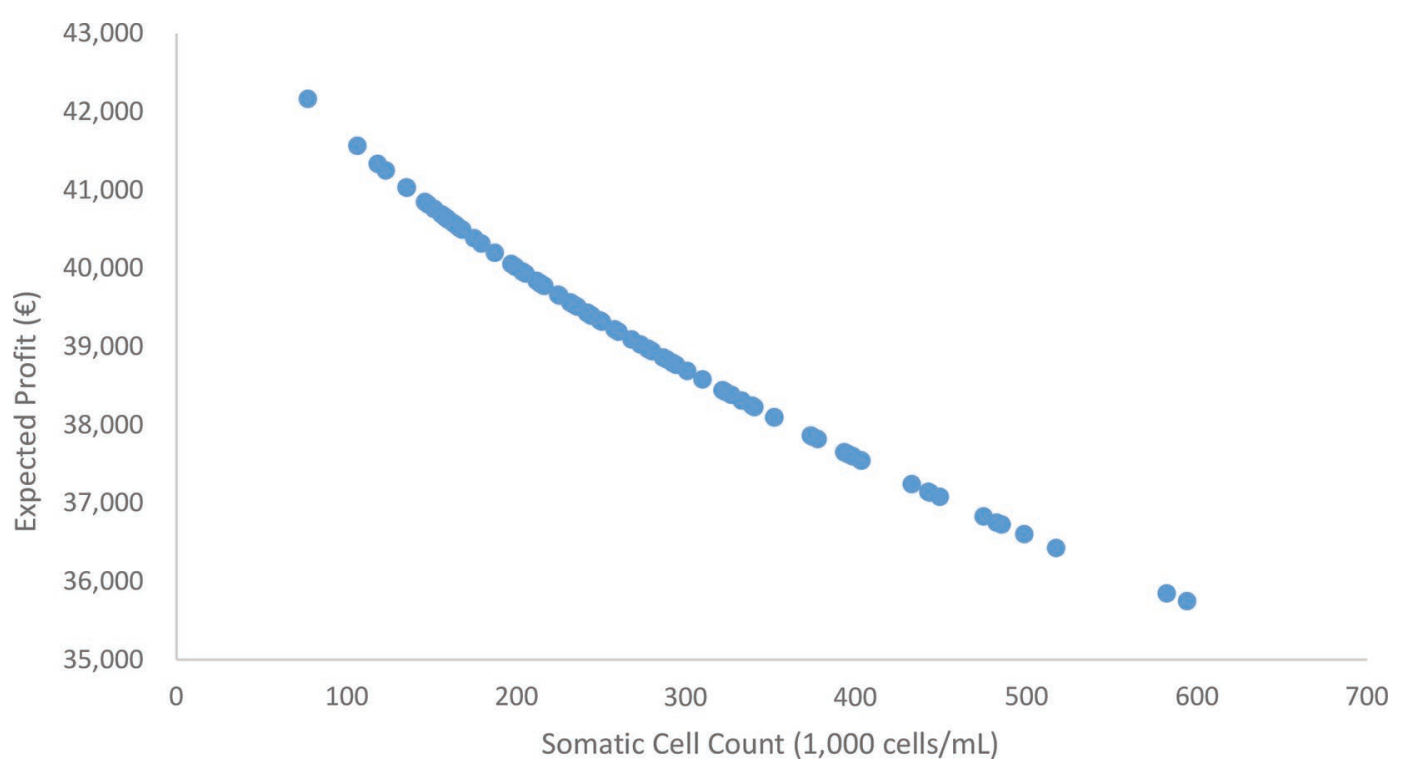

Figure 2. Effect of SCC on expected profit.

where a bar over a variable refer to the sample arithmetic mean of this variable, $\alpha=\frac{\sum_{i=1}^{197} \alpha_{i}}{197}$ represents the mean individual effect, and $\alpha_{2014}$ is the time effect for year 2014.

To measure the effect of SCC on technical efficiency and, by extension, on production, we calculated the expected technical efficiency index for the representative farm using the following equation:

$$
\begin{aligned}
& \ln \sigma_{u i 2004}^{2}=\delta_{0}+\delta_{\mathrm{SCC}} \ln \mathrm{SCC}_{i 2014}+\delta_{I} \ln \overline{\mathrm{CIN}}+\delta_{\mathrm{DFB}} \ln \overline{\mathrm{AFC}} \\
& +\delta_{\mathrm{CPC}} \ln \overline{\mathrm{CPC}}+\delta_{\mathrm{POL}} \overline{\mathrm{POL}}+\delta_{\mathrm{PFL}} \overline{\mathrm{PFL}}+\delta_{\mathrm{HA}} \overline{\mathrm{HA}}+\delta_{\mathrm{HA}^{2}} \overline{\mathrm{HA}}^{2}
\end{aligned}
$$

where $\mathrm{SCC}_{i 2014}$ refers to the values of the $\mathrm{SCC}$ variable for each farm $i$ in the year 2014 and the coefficient values $(\delta)$ correspond to the estimated parameters, and the determinants of efficiency other than SCC (i.e., CIN, AFC, CPC, POL, PFL, and HA) are set equal to their sample mean values. The SCC is then set equal to its observed value for each farm in year 2014, thereby generating a value of expected technical efficiency for the representative farm for each of the values of SCC observed in the last year of the sample, namely 2014. Expected production is then calculated by multiplying the efficient production by the expected technical efficiency scores. To convert the effect of changes in SCC into euros, we take the average price of milk received in the last year of the sample, 2014, as a reference. This was $0.373 € / \mathrm{L}$. Multiplying the predicted output levels by the price gives us the total revenue of the representative farm for each sample value of SCC. We calculated expected variable profit for the representative farm by subtracting sample average variable costs. Note here that we are assuming that the determinants of technical efficiency do not affect costs. This is a simplifying assumption, though it should be recognized that in reality some of these determinants may in fact affect costs (e.g., higher SCC may imply higher treatment costs for mastitis, and more open days will be associated with multiple inseminations with higher associated costs).

The relationship between expected (variable) profits and SCC is plotted in Figure 2. We carried out the same exercise for the CIN and AFC (noting that in these cases the representative farm has values of the determinants of inefficiency other than CIN and AFC equal to their sample means), and plotted the corresponding relationships between expected profits and the CIN and the AFC in Figures 3 and 4, respectively.

As can be seen, the variations in expected profits are quite substantial over the sample range of the health and reproductive indicators. In particular, as we go from the minimum to maximum observed SCC values, expected profit for the representative farm varies from $€ 42,169$ to $€ 35,748$, a drop of $15.2 \%$. For the CIN, expected profit falls from $€ 40,960$ to $€ 35,813$, a decrease of $12.6 \%$. For the AFC, expected profit falls from $€ 40,335$ to $€ 35,164$, a decrease of $12.8 \%$.

When plotting the graphs we are going from one extreme to the other of the observed values of the SCC, CIN, and AFC indicators. However, substantial changes 


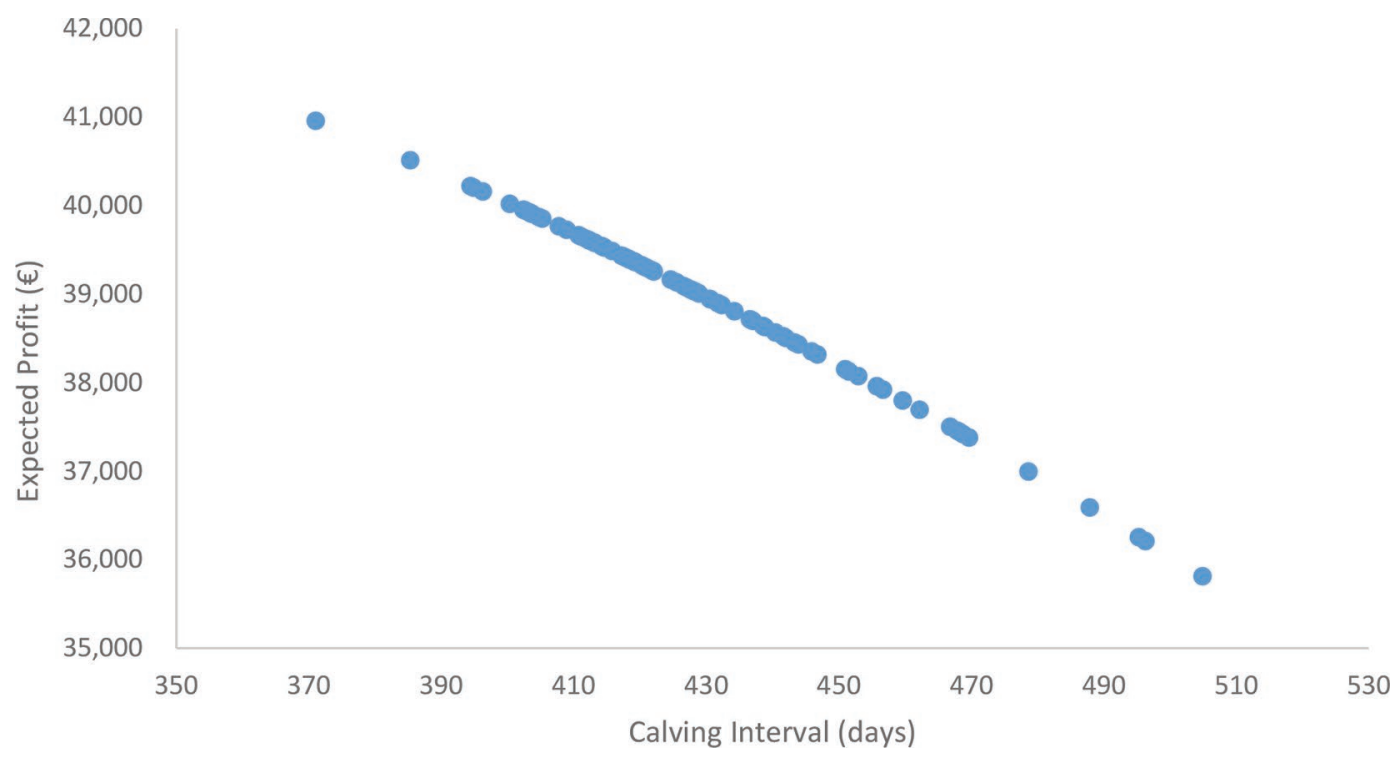

Figure 3. Effect of calving interval on expected profit.

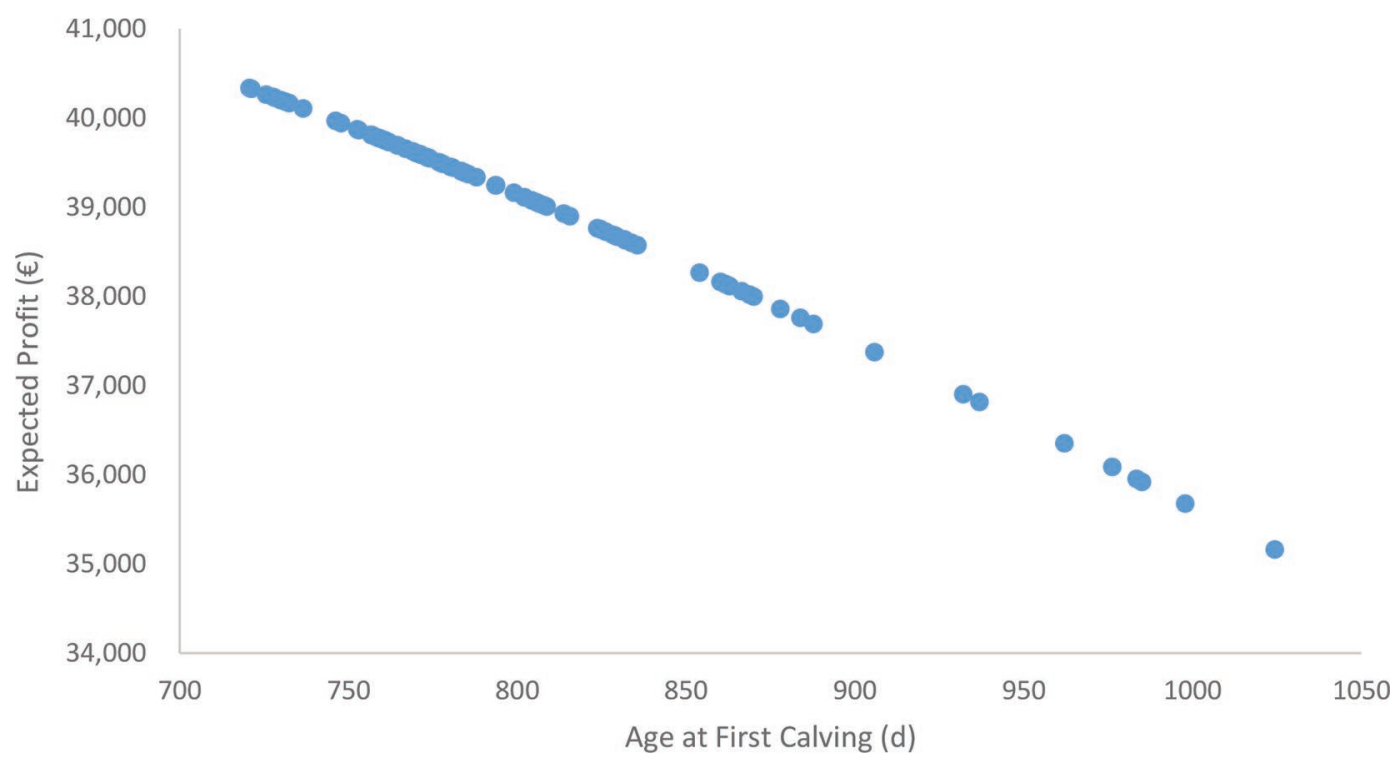

Figure 4. Effect of age at first calving on expected profit.

Table 5. Changes in profits ( $\pi$; in euro; $€ 1=\mathrm{US} \$ 1.214$ on December 31,2014$)$ for different values of SCC, calving interval (CIN), and age at first calving $(\mathrm{AFC})^{1}$

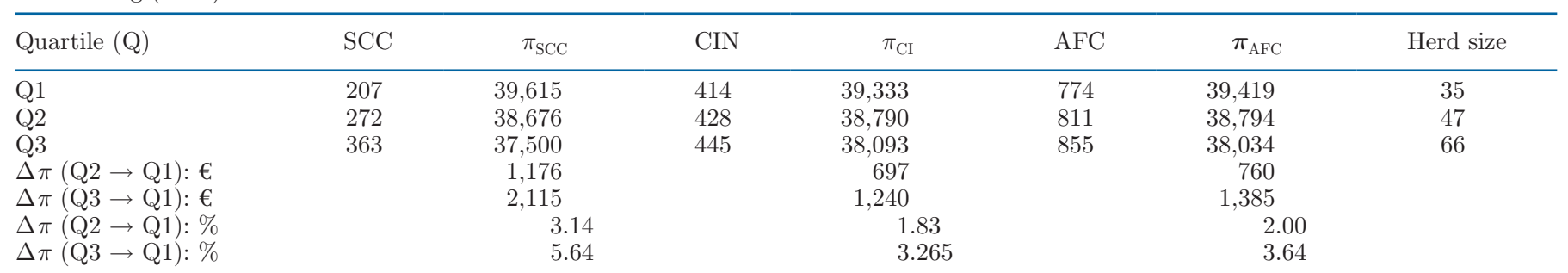

${ }^{1}$ Calculations based on simulation exercise showing expected profits corresponding to different quartile values of health and reproduction variables. $€$ refers to euro in the year 2014. 
Table 6. Direct effect of genetic index (GI) on profits ${ }^{1}$

\begin{tabular}{lcccccc}
\hline $\begin{array}{l}\text { GI quartile } \\
\text { (Q) }\end{array}$ & GI value & Milk $(\mathrm{L})$ & $\begin{array}{c}\text { Profits } \\
(€)\end{array}$ & $\begin{array}{c}\Delta \text { Profits } \\
(€)\end{array}$ & $\begin{array}{c}\Delta \text { Profits } \\
(\%)\end{array}$ & $\begin{array}{c}\text { Herd } \\
\text { size }\end{array}$ \\
\hline Q1 & -183 & 445,793 & 36,352 & & & 35 \\
Q2 & -20 & 453,098 & 39,082 & 2,730 & 7.5 & 47 \\
Q3 & 133 & 459,944 & 41,640 & 5,288 & 14.5 & 66 \\
\hline 1
\end{tabular}

${ }^{1} €$ refers to euro in the year 2014 ( $€ 1=$ US $\$ 1.214$ on December 31,2014$)$.

in profits can also be found for more modest changes in observed values. In Table 5, we present the expected profits for the representative farm corresponding to the first, second, and third quartile values of the SCC $\left(\pi_{\mathrm{SCC}}\right)$, CIN $\left(\pi_{\mathrm{CIN}}\right)$, and $\mathrm{AFC}\left(\pi_{\mathrm{AFC}}\right)$.

The last 4 rows show the absolute and percentage changes in expected profits when the values of health and reproduction indicators decrease from their second and third quartile values to their first quartile value. As can be seen in last row of the table, reducing the SCC from the third quartile to the first quartile value would lead to an increase in profits of $5.6 \%$. Similarly, reducing the CIN and AFC from their third quartile values to first quartile values would increase profits by 3.3 and $3.6 \%$ respectively.

To finish, we examine the effect of changes in the GI on profits through both its direct effect on animal productivity as well as its indirect effect via its effects on the animal health and reproduction variables. To evaluate the effects of GI on milk production we simulated the expected $(\log )$ of the efficient production by including the first, second, and third quartile values of GI and in the frontier. Again, the reference year is 2014. Efficient production (in year 2014) is calculated as

$$
\begin{aligned}
& \ln y_{Q h}=\alpha+\sum_{j=1}^{6} \beta_{j} \ln \overline{x_{j}}+\frac{1}{2} \sum_{j=1}^{6} \sum_{k=1}^{6} \beta_{j k} \ln \overline{x_{j}} \ln \overline{x_{k}} \\
& +\beta_{G I} \ln G I_{Q h}+\alpha_{2014},
\end{aligned}
$$

where subscript $Q h$ refers to the different quartiles considered (quartile 1 , quartile 2 , and quartile 3 ).

The first set of calculations, presented in Table 6 , uses the estimated coefficient of GI from [1], shown in Table 2, to calculate the effect of genetics on milk production and on profits. This direct effect captures the effect on production (and thereby profits) of increased animal productivity. Increases in GI from its first quartile value to its second and third quartile values generate increases in expected profits of 7.5 and $14.5 \%$, respectively.

Aside from the direct effect on production through increased productivity, genetics influences the health and reproduction variables as we see in the results presented in Table 4. Therefore, we present a second set of calculations that uses the results from the auxiliary regressions [4], [5], and [6] to estimate the global or overall effect of genetics by incorporating the indirect effect this variable has on production and profits through its effect on the health and reproduction variables and, as a consequence, on technical inefficiency. Table 7 shows the adjustments to the SCC, CIN, and AFC indicators for different values of GI based on the parameter estimates of equations (4) to (6). This allows us to adjust the SCC value by adding the increase in the variable corresponding to each quartile of the GI to the sample mean:

$$
\mathrm{SCC}_{Q h}=\overline{\mathrm{SCC}}+\gamma_{\mathrm{GI}}\left(\mathrm{GI}_{Q h}-\overline{\mathrm{GI}}\right)
$$

Adjustments to CIN and AFC are made in the same way. Fixing the other determinants of technical efficiency equal to their sample means, these adjustments to SCC, CIN, and AFC will lead to changes in technical efficiency. The profit figures shown in Table 7 are calculated taking into account both the direct effect of genetics on production as well as the indirect effect of GI due to changes in technical efficiency brought about by changes in the health and reproduction variables. Finally, Table 8 compares the effect of genetics on prof-

Table 7. Overall effect of genetic index (GI) on profits ${ }^{1}$

\begin{tabular}{lcccccccrr}
\hline $\begin{array}{l}\text { GI quartile } \\
\text { (Q) }\end{array}$ & $\begin{array}{c}\text { GI } \\
\text { value }\end{array}$ & $\begin{array}{c}\text { Adj. } \\
\text { SCC }\end{array}$ & $\begin{array}{c}\text { Adj. } \\
\text { CIN }\end{array}$ & $\begin{array}{c}\text { Adj. } \\
\text { AFC }\end{array}$ & $\begin{array}{c}\text { Milk } \\
(\mathrm{L})\end{array}$ & $\begin{array}{c}\text { Profits } \\
(€)\end{array}$ & $\begin{array}{c}\Delta \text { Profits } \\
(€)\end{array}$ & $\begin{array}{c}\Delta \text { Profits } \\
(\%)\end{array}$ & $\begin{array}{c}\text { Herd } \\
\text { size }\end{array}$ \\
\hline Q1 & -183 & 287 & 429 & 824 & 446,191 & 36,501 & - & 35 \\
Q2 & -20 & 295 & 432 & 821 & 453,090 & 39,079 & 2,578 & 7.1 \\
Q3 & 133 & 303 & 434 & 819 & 459,541 & 41,490 & 4,989 & 47 \\
\hline
\end{tabular}

${ }^{1}$ Adj. = adjusted; CIN calving interval; AFC = age at first calving. $€$ refers to euro in the year 2014 (€1 = US $\$ 1.214$ on December 31, 2014). 
Table 8. Differences between overall and direct effect of genetic index (GI) on profits ${ }^{1}$

\begin{tabular}{lcccc}
\hline & $\begin{array}{c}\Delta \text { Profits }(€): \\
\text { direct effect of GI } \\
\text { (A) }\end{array}$ & $\begin{array}{c}\Delta \text { Profits }(€): \\
\text { global effect of GI } \\
\text { GI }\end{array}$ & $\begin{array}{c}\text { Difference } \\
(€)\end{array}$ & $\begin{array}{c}\text { Difference } \\
(\%)\end{array}$ \\
\hline $\mathrm{Q} 1 \rightarrow \mathrm{Q} 2$ & 2,730 & 2,578 & $(\mathrm{~A})-(\mathrm{B})$ & $(\mathrm{A})-(\mathrm{B})$ \\
$\mathrm{Q} 1 \rightarrow \mathrm{Q} 3$ & 5,288 & 4,989 & -152 & -5.9 \\
\hline${ }^{1} \mathrm{Q}=$ quartile. $€$ refers to euro in the year $2014(€ 1=$ US $\$ 1.214$ on December 31,2014$)$. & -6.0
\end{tabular}

its with and without adjustments to the health and reproduction variables. If we do not take into account the effects of genetics on the health and reproduction variables, then profits increase by $€ 2,730$ when the GI for the herd increases from its first quartile value to its second quartile value, and by $€ 5,288$ when it increases to its third quartile value [column (A)]. When the effect on technical efficiency is taken into account, the corresponding increases in profits, shown in column (B), are slightly lower. The final column of Table 8 shows that the expected increases in profits from increases in GI from first to second and third quartile values are $6 \%$ lower when taking the effects of genetics on SCC, CIN, and AFC into account. Although this is not a large number, the more general point is that a correct evaluation of the expected benefits of increasing the genetics indicators of a herd should take into account the adverse effects of genetic change on health and reproduction indicators as these will affect technical efficiency. It appears that genetic selection has been motivated by increasing cow output rather than improving the health of the cow.

\section{CONCLUSIONS}

In this study we used a tool from production economics (stochastic frontier analysis) to analyze the effect of animal health and reproduction indicators on milk production and profits for a sample of Spanish dairy farms observed over the period 2006-2014. The indicators used were SCC, AFC, and CIN. We also controlled for genetic indicators of the herd. Insofar as these indicators capture aspects of animal health, they can be considered as measures of animal welfare. As the health and reproductive variables can be considered to be under the control of the farmer to a large extent, this points to the possibility of efficiency gains through improved management and better practice. We quantified this by estimating the effects of these animal welfare indicators on production and profits through their effects on technical efficiency. Moderate improvements in the values of the indicators can lead to significant efficiency and profit improvements. For example, we estimated that decreasing the SCC from its third quartile value to its first quartile value would increase profits by almost $6 \%$. We also quantified the effect of genetic selection on profits, showing that gains from direct productivity improvements are tempered to a slight extent by the adverse effects of genetic selection on technical efficiency arising from the changes it brings about in the health and reproduction variables.

\section{ACKNOWLEDGMENTS}

The authors are grateful to the Department of Rural Development and Natural Resources of the Regional Government of the Principality of Asturias (Oviedo, Asturias, Spain), the Asturian Dairy Farm Management Program (AGELES; Oviedo, Asturias, Spain), and Asturian Milk Control Cooperative (ASCOL; Gijón, Asturias, Spain) for their collaboration. Financial support for this research was provided by the Spanish Ministry of Economics and Competitiveness through the project "Sustainability and competitiveness in the dairy sector" (MINECO-13-ECO2013-46432-R). The authors have not stated any conflicts of interest.

\section{REFERENCES}

Allendorf, J. J., and P. J. C. Wettemann. 2015. Does animal welfare influence dairy farm efficiency? A two-stage approach. J. Dairy Sci. 98:7730-7740. https://doi.org/10.3168/jds.2015-9390.

Barnes, A. P., K. M. D. Rutherford, F. M. Langford, and M. J. Haskell. 2011. The effect of lameness prevalence on technical efficiency at the dairy farm level: An adjusted data envelopment analysis approach. J. Dairy Sci. 94:5449-5457. https://doi.org/10 $.3168 /$ jds.2011-4262.

Cabrera, V. E., D. Solís, and J. del Corral. 2010. Determinants of technical efficiency among dairy farms in Wisconsin. J. Dairy Sci. 93:387-393. https://doi.org/10.3168/jds.2009-2307.

Campos, M. S., C. J. Wilcox, C. M. Becerril, and A. Diz. 1994. Genetic parameters for yield and reproductive traits of Holstein and Jersey cattle in Florida. J. Dairy Sci. 77:867-873. https://doi.org/ 10.3168/jds.S0022-0302(94)77021-1.

Carlén, E., E. Strandberg, and A. Roth. 2004. Genetic parameters for clinical mastitis, somatic cell score, and production in the first three lactations of Swedish Holstein cows. J. Dairy Sci. 87:30623070. https://doi.org/10.3168/jds.S0022-0302(04)73439-6.

Castillo-Juarez, H., P. A. Oltenacu, and E. G. Cienfuegos-Rivas. 2002. Genetic and phenotypic relationships among milk production and composition traits in primiparous Holstein cows in two different herd environments. Livest. Prod. Sci. 78:223-231. https://doi.org/ 10.1016/S0301-6226(02)00098-2.

Caudill, S. B., J. M. Ford, and D. M. Gropper. 1995. Frontier estimation and firm-specific inefficiency measures in the presence of het- 
eroscedasticity. J. Bus. Econ. Stat. 13:105-111. https://doi.org/10 $.1080 / 07350015.1995 .10524583$.

Cuesta, R. A. 2000. A production model with firm-specific temporal variation in technical inefficiency: With application to Spanish dairy farms. J. Prod. Anal. 13:139-158. https://doi.org/10.1023/ A:1017297831646.

del Corral, J., J. A. Perez, and D. Roibas. 2011. The impact of land fragmentation on milk production. J. Dairy Sci. 94:517-525. https: //doi.org/10.3168/jds.2010-3377.

Dodenhoff, J., D. Sprengel, J. Duda, and L. Dempfle. 1999. Potential use of parameters of the milk flow curve for genetic evaluation of milkability. Interbull Bull. 23:131-141.

Dohoo, I. R., and A. H. Meek. 1982. Somatic cell counts in bovine milk. Can. Vet. J. La Rev. Vet. Can. 23:119-125.

Dono, G., L. Giraldo, and E. Nazzaro. 2013. Contribution of the calving interval to dairy farm profitability: Results of a cluster analysis of FADN data for a major milk production area in southern Italy. Span. J. Agric. Res. 11:857. https://doi.org/10.5424/sjar/2013114 $-3873$.

Eastham, N. T., A. Coates, P. Cripps, H. Richardson, R. Smith, and G. Oikonomou. 2018. Associations between age at first calving and subsequent lactation performance in UK Holstein and HolsteinFriesian dairy cows. PLoS One 13:e0197764. https://doi.org/10 .1371/journal.pone.0197764.

Eurostat. 2015. Structure of Agricultural Holdings by Region, Main Indicators. Accessed Feb. 15, 2019. http://epp.eurostat.ec.europa .eu.

Fraser, A. F., and D. Broom. 1990. Farm Animal Behaviour and Welfare. Baillière Tindall, East Kilbride, Scotland.

Ghavi Hossein-Zadeh, N. 2011. Estimation of genetic and phenotypic relationships between age at first calving and productive performance in Iranian Holsteins. Trop. Anim. Health Prod. 43:967-973. https://doi.org/10.1007/s11250-011-9791-7.

Greene, W. H. 2018. Econometric Analysis. Pearson, London, United Kingdom.

Halasa, T., K. Huijps, O. Østerås, and H. Hogeveen. 2007. Economic effects of bovine mastitis and mastitis management: A review. Vet. Q. 29:18-31. https://doi.org/10.1080/01652176.2007.9695224.

Hansson, H., G. Manevska-Tasevska, and M. Asmild. 2018. Rationalising inefficiency in agricultural production - The case of Swedish dairy agriculture. Eur. Rev. Agric. Econ. https://doi.org/10.1093/ erae/jby042.

Hansson, H., and B. Öhlmér. 2008. The effect of operational managerial practices on economic, technical and allocative efficiency at Swedish dairy farms. Livest. Sci. 118:34-43. https://doi.org/10 .1016/j.livsci.2008.01.013.

Hansson, H., M. Szczensa-Rundberg, and C. Nielsen. 2011. Which preventive measures against mastitis can increase the technical efficiency of dairy farms? Animal 5:632-640. https://doi.org/10 $.1017 /$ S1751731110002247.

Harmon, R. J. 1994. Physiology of mastitis and factors affecting somatic cell counts. J. Dairy Sci. 77:2103-2112. https://doi.org/10 .3168/jds.S0022-0302(94)77153-8.

Harvey, D., and C. Hubbard. 2013. Reconsidering the political economy of farm animal welfare: An anatomy of market failure. Food Policy 38:105-114. https://doi.org/10.1016/j.foodpol.2012.11.006.

Henningsen, A., T. G. Czekaj, B. Forkman, M. Lund, and A. S. Nielsen. 2018. The relationship between animal welfare and economic performance at farm level: A quantitative study of Danish pig producers. J. Agric. Econ. 69:142-162. https://doi.org/10 $1111 / 1477-9552.12228$

Hewson, C. J. 2003. What is animal welfare? Common definitions and their practical consequences. Can. Vet. J. 44:496-499.

Huijps, K., T. J. Lam, and H. Hogeveen. 2008. Costs of mastitis: Facts and perception. J. Dairy Res. 75:113-120. https://doi.org/ 10.1017/S0022029907002932.

Kadarmideen, H. N., R. Thompson, and G. Simm. 2000. Linear and threshold model genetic parameters for disease, fertility and milk production in dairy cattle. Anim. Sci. 71:411-419. https://doi.org/ 10.1017/S1357729800055338.
Key, N., and S. Sneeringer. 2014. Potential effects of climate change on the productivity of U.S. dairies. Am. J. Agric. Econ. 96:1136-1156. https://doi.org/10.1093/ajae/aau002.

Kumbhakar, S., and C. A. K. Lovell. 2000. Stochastic Frontier Analysis. Cambridge University Press, Cambridge, United Kingdom.

Lawson, L. G., J. F. Agger, M. Lund, and T. Coelli. 2004a. Lameness, metabolic and digestive disorders, and technical efficiency in Danish dairy herds: A stochastic frontier production function approach. Livest. Prod. Sci. 91:157-172. https://doi.org/10.1016/ j.livprodsci.2004.07.016.

Lawson, L. G., J. Bruun, T. Coelli, J. F. Agger, and M. Lund. 2004b. Relationships of efficiency to reproductive disorders in Danish milk production: A stochastic frontier analysis. J. Dairy Sci. 87:212-224. https://doi.org/10.3168/jds.S0022-0302(04)73160-4.

Lee, L.-F., and W. G. Tyler. 1978. The stochastic frontier production function and average efficiency: An empirical analysis. J. Econom. 7:385-389. https://doi.org/10.1016/0304-4076(78)90061-1.

Lusk, J. L., and F. B. Norwood. 2011. Animal welfare economics. Appl. Econ. Perspect. Policy 33:463-483. https://doi.org/10.1093/ aepp/ppr036.

McConnel, C. S., J. E. Lombard, B. A. Wagner, and F. B. Garry. 2008. Evaluation of factors associated with increased dairy cow mortality on United States dairy operations. J. Dairy Sci. 91:1423-1432. https://doi.org/10.3168/jds.2007-0440.

McInerney, J. P. 2004. Animal Welfare, Economics and Policy. Report prepared for Defra, London, United Kingdom.

Mostert, B. E., H. E. Theron, and F. H. Kanfer. 2001. The effect of calving season and age at calving on production traits of South African dairy cattle. S. Afr. J. Anim. Sci. 31:205-214. https://doi .org/10.4314/sajas.v31i3.3795.

Mukherjee, D., B. E. Bravo-Ureta, and A. De Vries. 2013. Dairy productivity and climatic conditions: econometric evidence from South-eastern United States. Aust. J. Agric. Resour. Econ. 57:123140. https://doi.org/10.1111/j.1467-8489.2012.00603.x.

Nieuwhof, G. J., R. L. Powell, and H. D. Norman. 1989. Ages at calving and calving intervals for dairy cattle in the United States. J. Dairy Sci. 72:685-692. https://doi.org/10.3168/jds.S0022 -0302(89)79160-8.

Oltenacu, P. A., and B. Algers. 2005. Selection for increased production and the welfare of dairy cows: Are new breeding goals needed? Ambio 34:311-315. https://doi.org/10.1579/0044-7447-34.4.311.

Orea, L., J. A. Perez, and D. Roibas. 2015. Evaluating the double effect of land fragmentation on technology choice and dairy farm productivity: A latent class model approach. Land Use Policy 45:189-198. https://doi.org/10.1016/j.landusepol.2015.01.016.

Pérez-Méndez, J. A., D. Roibas, and A. Wall. 2019. The influence of weather conditions on dairy production. Agric. Econ. (United Kingdom) 50:165-175. https://doi.org/10.1111/agec.12474.

Pritchard, T., M. Coffey, R. Mrode, and E. Wall. 2013. Genetic parameters for production, health, fertility and longevity traits in dairy cows. Animal 7:34-46. https://doi.org/10.1017/ S1751731112001401.

Pryce, J. E., M. P. Coffey, and S. Brotherstone. 2000. The genetic relationship between calving interval, body condition score and linear type and management traits in registered Holsteins. J. Dairy Sci. 83:2664-2671. https://doi.org/10.3168/jds.S0022-0302(00)75160 -5 .

Pryce, J. E., M. D. Royal, P. C. Garnsworthy, and I. L. Mao. 2004 Fertility in the high-producing dairy cow. Livest. Prod. Sci 86:125-135. https://doi.org/10.1016/S0301-6226(03)00145-3.

Qi, L., B. E. Bravo-Ureta, and V. E. Cabrera. 2015. From cold to hot: Climatic effects and productivity in Wisconsin dairy farms. J. Dairy Sci. 98:8664-8677. https://doi.org/10.3168/jds.2015-9536.

Roibas, D., and A. Alvarez. 2010. Impact of genetic progress on the profits of dairy farmers. J. Dairy Sci. 93:4366-4373. https://doi .org $/ 10.3168 /$ jds.2010-3135.

Ruiz-Sánchez, R., R. W. Blake, H. M. A. Castro-Gámez, F. Sánchez, H. H. Montaldo, and H. Castillo-Juárez. 2007. Short Communication: Changes in the association between milk yield and age at first calving in Holstein cows with herd environment level for 
milk yield. J. Dairy Sci. 90:4830-4834. https://doi.org/10.3168/ jds.2007-0156.

Schulte, H. D., L. Armbrecht, R. Bürger, M. Gauly, O. Musshoff, and S. Hüttel. 2018. Let the cows graze: An empirical investigation on the trade-off between efficiency and farm animal welfare in milk production. Land Use Policy 79:375-385. https://doi.org/10.1016/ j.landusepol.2018.07.005.

Sherwin, V. E., C. D. Hudson, A. Henderson, and M. J. Green. 2016. The association between age at first calving and survival of first lactation heifers within dairy herds. Animal 10:1877-1882. https:/ /doi.org/10.1017/S1751731116000689.

Vacek, M., L. Stádník, and M. Štípková. 2008. Relationships between the incidence of health disorders and the reproduction traits of Holstein cows in the Czech Republic. Czech J. Anim. Sci. 52:227235. https://doi.org/10.17221/2278-CJAS.

von Keyserlingk, M. A. G., J. Rushen, A. M. de Passillé, and D. M. Weary. 2009. Invited review: The welfare of dairy cattle-Key con- cepts and the role of science. J. Dairy Sci. 92:4101-4111. https:// doi.org/10.3168/jds.2009-2326.

Wilmink, J. B. M. 1987. Adjustment of test-day milk, fat and protein yield for age, season and stage of lactation. Livest. Prod. Sci. 16:335-348. https://doi.org/10.1016/0301-6226(87)90003-0.

Zhao, F., G. Guo, Y. Wang, X. Guo, Y. Zhang, and L. Du. 2015. Genetic parameters for somatic cell score and production traits in the first three lactations of Chinese Holstein cows. J. Integr. Agric. 14:125-130. https://doi.org/10.1016/S2095-3119(14)60758-9.

\section{ORCIDS}

Jose A. Pérez-Méndez @ \ttps://orcid.org/0000-0002-2916-6472

David Roibás @ https://orcid.org/0000-0001-9904-0085

Alan Wall @ https://orcid.org/0000-0001-5090-9253 